Vol. 06 No. 01 Februari

ISSN 2339-1502

\title{
TINJAUAN PERLAKUAN DAN PENYAJIAN AKUNTANSI PENDAPATAN PADA PEMERINTAH KOTA PALOPO
}

\author{
Hijriah \\ Jurusan Akuntansi Audit Internal, Universitas Muhammadiyah (UM) Palopo \\ hijriahalimuddin750@gmail.com
}

\begin{abstract}
ABSTRAK
Penelitian ini bertujuan untuk mengetahui Perlakuan dan Penyajian Akuntansi Pendapatan Pada Pemerintah Kota Palopo. Penelitian ini menggunakan metode analisis deskriptif dengan menggunakan data sekunder yang diperoleh dari data laporan keuangan Laporan Realisasi Anggaran (LRA) dan data laporan keuangan Laporan Operasional (LO). Penelitian ini menemukan bahwa perlakuan akuntansi pendapatan pada Pemerintah Daerah Kota Palopo telah sesuai dengan Peraturan Pemerintah Nomor 71 Tahun 2010 tentang Standar Akuntansi Pemeintah dimana dalam Laporan Realisasi Anggaran (LRA) di akui pada saat kas di terima di kas umum daerah, sedangkan dalam Laporan Operasional ( $L O)$ di akui sebagai penambah ekuitas. Adapun penyajian akuntansi pendapatan pada Pemerintah Daerah Kota Palopo telah sesuai dengan Peraturan Pemerintah Nomor 71 Tahun 2010 tentang Standar Akuntansi Pemeintah dimana dalam Laporan Realisasi Anggaran (LRA) yaitu membandingkan antara anggaran dan realisasinya dan menyajikan unsur-unsur pendapatan, belanja, surplus/defisit, pembiayaan dan sisa lebih/kurang pembiayaan anggaran, sedangkan dalam Laporan Operasional (LO) menyajikan unsur-unsur pendapatan-LO, beban, surplus/defisit dari kegiatan operasional, surplus/defisit dari pos luar biasa, pos luar biasa dan difisit $L O$.
\end{abstract}

Kata Kunci : Perlakuan Akuntansi, Penyajian Akuntansi, Laporan Realisasi Anggara, (LRA), Laporan

Operasional ( $L O)$

\begin{abstract}
This study aims to determine the Treatment and Presentation of Income Accounting in the City Government of Palopo. This research uses descriptive analysis method by using secondary data obtained from the data of the Budget Realization Report (LRA) and Operational Report (LO) financial report data. This study found that the accounting treatment of income in the Palopo City Government was in accordance with Government Regulation No. 71 of 2010 concerning Government Accounting Standards where in the Budget Realization Report (LRA) was recognized when cash was received at the regional general cash, whereas in the Operational Report ( LO) is recognized as an equity enhancer. The presentation of income accounting in the Regional Government of Palopo City is in accordance with Government Regulation Number 71 of 2010 concerning Government Accounting Standards where in the Budget Realization Report (LRA), which compares the budget and its realization and presents elements of income, expenditure, surplus / deficit, financing and the remaining / less budget financing, while in the Operational Report $(L O)$ presents elements of income-LO, expenses, surplus / deficit from operational activities, surplus / deficit from extraordinary items, extraordinary items and LO deficits.
\end{abstract}

Keywords: Accounting Treatment, Accounting Presentation, Anggara Realization Report, (LRA), Operational Report (LO).

\section{PENDAHULUAN}

Lembaga Pemerintah dalam menjalankan roda pemerintahannya juga mengelola keuangan Negara. Dalam UU No. 17 Tahun 2003 Tentang Keuangan Negara, khususnya pasal 1 ayat 1 dinyatakan bahwa pengertian keuangan negara adalah semua hak dan kewajiban negara yang dapat dinilai dengan uang, serta segala sesuatu baik berupa uang maupun berupa barang yang dapat 
dijadikan milik negara berhubung dengan pelaksanaan hak dan kewajiban tersebut. (Hariyanto, 2012).

Dalam kaitannya dengan keuangan negara Pemerintah berkewajiban untuk melaksanakan pengelolaan keuangan negara secara tertib, taat pada peraturan perundang- undangan, efisien, ekonomis, efektif, dan transparan, dengan memperhatikan rasa keadilan dan kepatutan. Untuk mencapai tujuan tersebut, beberapa tahun terakhir ini pemerintah mencoba untuk mencari basis akuntansi yang tepat agar dapat diterapkan dalam akuntansi pemerintahan. Sifat pemerintah yang unik, menjadikan basis akuntansi yang akan diterapkan menjadi kendala tersendiri. (Hariyanto, 2012).

Pada tahun 2010, pemerintah mengeluarkan peraturan baru tentang standar akuntansi pemerintahan, melalui PP Nomor 71 Tahun 2010, yang mengatur tentang penggunaan basis akrual dalam pengelolaan dan pelaporan keuangan pemerintah, untuk menggantikan PP Nomor 24 Tahun 2005 (Nurtanzila, 2013).

Dengan diterbitkannya PP No.71 Tahun 2010 tentang SAP yang akan digunakan untuk menghasilkan suatu laporan keuangan yang andal dan dapat dijadikan pijakan dalam pengambilan keputusan dan yang di harapkan dapat menjadi acuan, patokan serta standar untuk diterapkan dalam lingkup pemerintahan, yaitu pemerintah pusat, pemerintah daerah dan satuan organisasi dilingkungan pemerintah pusat/daerah yang wajib untuk menyajikan laporan keuangan agar lebih terciptanya akuntabilitas dan transparansi dari pengelolaan keuangan daerah tersebut. (Langelo. 2015).

Berdasarkan Peraturan Pemerintah Nomor 71 tentang Standar Akuntansi Pemerintahan (SAP), Komponen-komponen yang terdapat dalam satu set laporan keuangan berbasis akrual terdiri dari laporan pelaksanaan anggaran (budgetary reports) dan laporan finansial, yang jika diuraikan adalah, Laporan Realisasi Anggaran, Laporan Perubahan Saldo Anggaran Lebih, Laporan Operasional, Laporan Perubahan Ekuitas, Neraca, Laporan Arus Kas, dan Catatan atas Laporan Keuangan.

Dalam penelitian ini akan dibahas dua laporan keuangan pemerintah daerah yaitu Laporan Realisasi Anggaran yang berbasis Kas dan Laporan Operasional yang berbasis akrual.

Basis akrual merupakan basis akuntansi yang mengakui pengaruh suatu transaksi pada saat terjadinya, tanpa memperhatikan saat kas atau setara kas diterima atau dibayar (Kawedar, et. 
al., 2008: 86). Standar akuntansi pemerintah berbasis akrual ini diadopsi dari keberhasilan pemerintah negara-negara maju untuk meningkatkan akuntabilitas dan transparansi keuangan pemerintah, seperti Selandia Baru, Australia, Amerika Serikat, Inggris dan Swedia, serta menjadi kesatuan reformasi dalam bidang pengelolaan keuangan pemerintah. (Nurtanzila, 2013).

Basis akrual akuntansi pendapatan-LO mengakui pengaruh transaksi penghasil pendapatan atau peristiwa lain penghasil pendapatan pada saat transaksi atau peristiwa penyebab timbulnya hak atas pendapatan terjadi, tanpa memerhatikan saat pendapatan tersebut diterima dalam bentuk tunai atau bentuk penerimaan lain, yang dimodifikasi sejalan dengan sub-sub definisi tentang basis akrual pada lampiran 1.02 PSAP 01, karena itu pengakuan akuntansi pendapatan basis penerimaan Kas Umum Negara (KUN) / Kas Umum Daerah (KUD) merupakan penyimpangan dari standar berbasis akrual paripurna. (Agoes, dkk. 2013)

Pendapatan-LO adalah hak pemerintah pusat/daerah yang diakui sebagai penambah ekuitas dalam periode tahun anggaran yang bersangkutan dan tidak perlu dibayar kembali. (PP No. 71 Tahun 2010).

Menurut Halim (2004:39) Basis kas adalah basis akuntansi yang paling sederhana. Menurut basis ini transaksi diakui atau dicatat apabila manimbulkan perubahan atau berakhir pada kas, yaitu menaikan atau menurunkan kas. Apabila transaksi tersebut tidak berpengaruh pada kas maka transaksi tersebut tidak akan dicatat.

Pendapatan-LRA adalah semua penerimaan Rekening Kas Umum Negara/Daerah yang menambah Saldo Anggaran Lebih dalam periode tahun anggaran yang bersangkutan yang menjadi hak pemerintah, dan tidak perlu dibayar kembali oleh pemerintah. (PP No. 71 Tahun 2010).

Tujuan standar Laporan Realisasi Anggaran adalah menetapkan dasar-dasar penyajian Laporan Realisasi Anggaran untuk pemerintah dalam rangka memenuhi tujuan akuntabilitas sebagaimana ditetapkan oleh peraturan perundang-undangan dan memberikan informasi dan anggaran entitas pelaporan. Perbandingan antara anggaran dan menunjukkan tingkat ketercapaian target-target yang telah disepakati antara legislatif dan eksekutif sesuai dengan peraturan perundang- undangan. (PP No. 71 Tahun 2010). 


\section{Rumusan Masalah}

Berdasarkan latar belakang yang telah di urai di atas, maka rumusan masalah dalam penelitian ini adalah Bagaimana perlakuan akuntansi pendapatan pada Pemerintah Kota Palopo? Dan Bagaimana penyajian akuntansi pendapatan pada Pemerintah Kota Palopo ?

\section{Tujuan Penelitian}

Berdasarkan rumusan masalah yang telah diurai diatas maka tujuan dalam penelitian ini ada untuk mengetahui perlakuan akuntansi pendapatan pada Pemerintah Kota Palopo, dan untuk mengetahui penyajian akuntansi pendapatan pada Pemerintah Kota Palopo.

\section{TINJAUAN PUSTAKA}

\section{Perlakuan Akuntansi}

Menurut Poerwadarminta (2005:651) pengertian perlakuan adalah "perbuatan yang dikenakan kepada atau terhadap sesuatu atau orang”. Maksudnya adalah perbuatan atau tindakan yang dikenakan kepada sesuatu yang bukan orang maupun terhadap orang itu sendiri. Kaitannya dalam laporan keuangan adalah bagaimana unsur-unsur laporan keuangan itu dicatat dan disajikan.

Tepat atau belum tepatnya perlakuan akuntansi terhadap laporan keuangan dapat diketahui setelah diadakan analisis terhadap laporan keuangan dan unsurunsurnya. Analisis atau menganalisis menurut Syahrul dan Nizar (2000:48) adalah "melakukan evaluasi terhadap kondisi dan pos-pos atau ayat-ayat yang berkaitan dengan akuntansi dan alasan- alasan yang memungkinkan tentang perbedaan yang muncul”. Sedangkan menurut Poerwadarminta (2005:37) analisis adalah "penyelidikan suatu peristiwa (karangan, perbuatan, dan sebagainya) untuk mengetahui apa sebab-sebabnya, bagaimana duduk perkaranya dan sebagainya”.

Berdasarkan kedua pengertian diatas, dapat disimpulkan bahwa analisis atau menganalisis adalah melakukan evaluasi atau penyelidikan terhadap suatu kondisi dengan tujuan untuk mengetahui sebab-sebab atau alasan-alasan yangmemungkinkan terjadinya perbedaan. Kaitannya dengan perlakuan akuntansi terhadap laporan keuangan adalah melakukan penyelidikan atau evaluasi terhadap laporan keuangan dan unsur- unsurnya untuk mengetahui sebab-sebab atau alasan-alasan yang memungkinkan terjadinya perbedaan. Perbedaan yang muncul akan menyebabkan kurang tepatnya atau kurang wajarnya penyajian atas laporan keuangan. 
Perlakuan dalam akuntansi adalah proses penetapan terpenuhinya kriteria pencatatan suatu kejadian atau peristiwa dalam catatan akuntansi sehingga akan menjadi bagian yang melengkapi unsur aset, kewajiban, ekuitas, pendapatan-LRA, belanja, pembiayaan, pendapatan-LO, dan beban, sebagaimana akan termuat pada laporan keuangan entitas pelaporan yang bersangkutan. Pengakuan diwujudkan dalam pencatatan jumlah uang terhadap pos-pos laporan keuangan yang terpengaruh oleh kejadian atau peristiwa terkait. (PP 71 Tahun 2010).

Menurut Rahman (2012 : 25), ada beberapa konsep yang terkait dengan perlakuan akuntansi yaitu konsep pengakuan, konsep pengkuran/penilaian, konsep pencatatan, konsep penyajian, dan konsep pengungkapan.

\section{Penyajian Akuntansi}

Penyajian adalah aspek yang penting dari aksesibilitas. Dengan kata lain laporan keuangan minimalnya harus dapat dimengerti dan tersedia bagi mereka yang tertarik dan mau berusaha untuk memahaminya (Rohman: 2009).

Standar akuntansi pemerintah mengatur penyajian laporan keuangan untuk tujuan umum (general purpose financial statements) dalam rangka meningkatkan perbandingan laporan keuangan baik terhadap anggaran, antar periode, maupun antar entitas. (PP No. 71 Tahun 2010).

Laporan keuangan untuk tujuan umum adalah laporan keuangan yang ditujukan untuk memenuhi kebutuhan bersama sebagian besar pengguna laporan. Untuk mencapai tujuan tersebut, standar ini menetapkan seluruh pertimbangan dalam rangka penyajian laporan keuangan, pedoman struktur laporan keuangan, dan persyaratan minimum isi laporan keuangan. (PP No. 71 Tahun 2010).

\section{Pendapatan}

\section{Pendapatan Laporan Realisasi}

Anggaran (Pendapatan-LRA) Pendapatan Laporan Realisasi Anggaran (LRA) menurut PSAP No. 2 paragraf 7 adalah semua penerimaan rekening kas umum negara/daerah yang menambah saldo anggaran lebih dalam periode tahun anggaran yang bersangkutan yang menjadi hak pemerintah, dan tidak perlu dibayar kembali oleh pemerintah. Akuntansi Pendapatan-LRA menurut PSAP No. 2 Paragraf 24, 25, 27, 28, 29, dan 30 dilaksanakan berdasarkan asas bruto, yaitu dengan membukukan penerimaan bruto dan tidak mencatat jumlah netonya (setelah dikompensasikan 
dengan pengeluaran). Dalam hal besarnya pengurangan terhadap Pendapatan-LRA bruto (biaya) bersifat variable terhadap pendapatan dimaksud dan tidak dapat dianggarkan terlebih dahulu karena proses belum selesai, maka asas bruto dapat dikecualikan. Pengembalian yang sifatnya sistematika (normal) dan berulang (recurring) atas penerimaan pendapatan-LRA pada periode penerimaan maupun pada periode sebelumnya dibukukan sebagai pengurangan pendapatanLRA. Koreksi dan pengembalian yang sifatnya tidak berulang (nonrecurring) atas penerimaan pendapatan-LRA yang terjadi pada periode penerimaan pendapatan-LRA dibukukan sebagai pengurang pendapatan-LRA pada periode yang sama. Koreksi dan pengembalian yang sifatnya tidak berulang (nonrecurring) atas penerimaan pendapatan-LRA yang terjadi pada periode sebelumnya dibukukan sebagai pengurangan saldo anggaran lebih pada periode ditemukannya koreksi dan pengembalian tersebut. Akuntansi pendapatan-LRA disusun untuk memenuhi kebutuhan pertanggungjawaban sesuai dengan ketentuan dan untuk keperluan pengendalian bagi manajemen pemerintah pusat dan daerah. (Erlina, dkk 2010. Hal.110).

\section{Pendapatan Laporan Operasional}

(Pendapatan-LO) Laporan Operasional merupakan laporan yang menyajikan ikhtisar sumber daya ekonomi yang mempengaruhui ekuitas pemerintah dalam satu periode, laporan Operasional menyediakan informasi tentang kegiatan operasional keuangan entitas yang mencerminkan pendapatan, beban, serta surplus/defisit. Penyusunan laporan operasional dilakukan untuk melengkapi siklus pelaporan yang saling terkait. Keterkaitan pelaporan ini terlihat dari hubungan antara laporan operasional, laporan perubahan ekuitas, dan neraca. (Siregar. 2017. Hal. 147).

Pendapatan Laporan Operasional adalah hak pemerintah pusat/daerah yang diakui sebagai penambah ekuitas dalam periode tahun anggaran yang bersangkutan dan tidak perlu dibayar kembali. (PP No. 71 Tahun 2010).

Pendapatan-LO menurut PSAP No.12 paragraf 8 adalah hak pemerintah yang diakui sebagai penambah ekuitas dalam periode pelaporan yang bersangkutan. Sementara menurut Pemendagri No. 64 Tahun 2013, pendapatan-LO merupakan hak pemerintah daerah yang diakui sebagai penambah ekuitas dalam periode tahun anggaran yang bersangkutan dan tidak perlu dibayar kembali. Pendapatan-LO merupakan pendapatan yang menjadi tanggungjawab dan wewenang entitas pemerintah, baik yang dihasilkan oleh transaksi operasional, non operasional, dan pos luar biasa yang dapat meningkatkan ekuitas entitas pemerintah. 


\section{METODE PENELITIAN}

\section{Instrumen Penelitian}

Dalam penelitian deskriptif, peneliti merupakan instrumen utama dalam mengumpulkan data dan menginterpretasikan data berdasarkan persamaan persamaan jenis data dari data tersebut.

Agar penelitian ini terarah, peneliti terlebih dahulu menyusun kisi-kisi instrumen penelitian yang selanjutnya dijadikan acuan untuk membuat pedoman observasi.

\section{Sumber Data}

Sumber data yang digunaka adalah Data Sekunder. Berupa data Laporan Keuangan Laporan Realisasi Anggaran (LRA) dan Data Laporan Keuangan Laporan Operasional (LO) Pada Badan Pengelolaan Keuangan dan Aset Daerah Kota Palopo dan Pada Badan Pendapatan Daerah Kota Palopo.

\section{Teknik Pengumpulan Data}

Untuk mendapatkan data-data tersebut maka penulis akan menggunakan instrument Observasi, dalam instrumen observasi penulis akan melakukan pengamatan dilokasi penelitian untuk mendapatkan gambaran yang tepat mengenai subjek dan objek kajian.

\section{Teknik Analisa Data}

Analisa yang digunakan adalah analisa deskrptif yaitu mengungkapkan kejadian atau fakta, fenomena dan keadaan yang sebenarnya saat penelitian berlangsung dengan menyuguhkan apa yang sebenarnya terjadi.

Penelitian ini membandingkan data yang ada yaitu data Laporan Keuangan Pendapatan Laporan Operasional dan Laporan Keuangan Pendapatan Laporan Reaslisasi Anggaran.

\section{HASIL DAN PEMBAHASAN}

\section{Perlakuan Akuntansi Pendapatan Pada Bandan Pengelolaan Keuangan dan Aset Daerah (BPKAD) Kota Palopo terkait penerapan PP Nomor 71 Tahun 2010.}

Sebagaimana diamanatkan undang-undang Nomor 17 Tahun 2003 tentang Keuangan Negara bahwa Mentri/Pimpinan Lembaga Sebagai Pengguna Anggaran/Barang mempunyai tugas antara lain menyusun dan menyampaikan Laporan Keuangan Kementrian/Lembaga yang dipimpinnya. 
BPKAD Kota Palopo adalah salah satu entitas akuntansi yang berkewajiban menyelenggarakan akuntansi dan laporan pertanggungjawaban atas pelaksanaan Anggaran Pendapatan dan Belanja Daerah.

Adapun pelaksanaan pendapatannya adalah dengan menyusun Laporan Keuangan Pendapatan yang berupa Laporan Realisasi Anggaran (LRA) dan Laporan Operasional (LO). Penyusunan laporan keuangan BPKAD mengacu pada Peraturan Pemerintah Nomor 71 Tahun 2010 tentang Standar Akuntansi Pemerintah (SAP) dan kaidah-kaidah pengelolaan keuangan yang sehat dalam pemerintah.

Laporan Keuangan BPKAD Kota Palopo telah disusun dengan basis Kas pada Laporan Realisasi Anggaran dan Basis Akrual pada Laporan Operasional sehingga akan mampu menyajikan informasi keuangan yang transparan, akurat dan akuntabel. Laporan Keuangan diharapkan dapat memberikan informasi yang berguna kepada para pengguna Laporan Keuangan khususnya sebagai sarana untuk meningkatkan akuntabilitas/pertanggungjawaban dan transparansi pengelolaan keuangan Derah pada BPKAD Kota Palopo.

Dalam penlitian ini, peneliti mengumpulkan data menggunakan data sekunder. Data sekunder adalah data yang diperoleh peneliti dari berbagai sumber yang ada seperti buku, laporan, jurnal dan lain-lain yang terkait dengan Perlakuan dan Penyajian Akuntansi Pendapatan Laporan Realisasi Anggaran yang Berbasis Kas dan Laporan Operasional yang Berbasis Akrual pada Laporan Keuangan di BPKAD Kota Palopo.

Penjelasan yang didapatkan dari data yang dikumpulkan oleh peneliti adalah sebagai berikut :

a. Pengakuan dan Pengukuran Pendapatan Laporan Realisasi Anggaran (LRA) di BPKAD Kota Palopo.

b. Pendapatan-LRA di BPKAD Kota Palopo diakui pada saat kas diterima pada Kas Umum Daerah (KUD). Akuntansi Pendapatan- LRA dilaksanakan berdasarkan azas bruto, yaitu dngan membukukan penerimaan bruto, dan tidak mencatat jumlah nettonya (setelah dikompensasikan dengan pengeluaran). Pendapatan-LRA disajikan menurut klasifikasi sumber pendapatan.

c. Pengakuan dan Pengukuran Pendapatan Laporan Operasional di BPKAD Kota Palopo.

d. Pendapatan-LO adalah hak pemerintah daerah yang diakui sebagai penambah ekuitas dalam periode tahun anggaran yang bersangkutan dan tidak perlu dibayar kembali. 
Pendapatan-LO di BPKAD Kota Palopo diakui pada saat timbulnya hak atas pendapatan dan / atau pendapatan direalisasi, yaitu adanya aliran masuk sumber daya ekonomi. Akuntansi pendapatan-LO dilaksanakan berdasarkan azas bruto, yitu dengan membukuan pendapatan bruto, dan tidak mencatat jumlah nettonya (stelah dikomepensasikan dengan pengeluaran). Pendapatan-LO disajikan menurut klasifikasi sumber pendapatan.

\section{Penyajian Pendapatan Laporan Keuangan Badan Pengelolaan Keuangan Dan Aset Daerah (BPKAD) Kota Palopo.}

Anaslisi penerapan Peraturan Pemerintah Nomor 71 Tahun 2010 tentang SAP dalam penyajian Laporan Keuangan pada BPKAD Kota Palopo sebagai berikut:

a. Analisis Penyajian Pendapatan Laporan Realisasi Anggaran (LRA)

Dalam penyajian laporan keuangan BPKAD Kota Palopo dilaksanakan berdasarkan basis kas, berarti bahwa pendapatan-LRA dan penerimaan pembiayaan diakui pada saat kas diterima di rekening Kas Umum Daerah (KUD) atau oleh entitas pelaporan, serta belanaja, dan pengeluaran pembiayaan diakui pada saat kas dikeluarkan dari rekening Kas Umum Daerah. Laporan Realisasi Anggaran menggambarkan perbandingan antara anggaran dan realisasinya dalam satu periode pelaporan dan menyajikan unsur-unsur Pendapatan, Belanja, Surplus/Defisit, Pembiayaan dan Sisa Lebih/Kurang Pembiayaan Anggaran.

b. Relisasi Pendapatan Daerah pada Tahun Anggaran 2017 sebesar Rp.934.121.533.937,22 atau mencapai 96,78\% dari alokasi anggaran sebesar Rp.965.224.397.122,00, Realisasi Belanja Daerah Tahun Anggaran 2017 sebesar Rp.936.855.112.821,04 atau mencapai 94,89\% dari alokasi anggaran sebesar Rp.1.025.794.198.014,00, Realisasi Surplus/Defisit pada Tahun Anggaran 2017 sebesar (Rp.29.733.578.883,82) atau mencapai 58,80\% dari alokasi anggaran (Rp.50.569.800.829,00), Realisasi Pembiayaan Netto pada Tahun Anggaran 2017 sebesar Rp.52.569.802.763,56 atau mencapai 103,95\% dari alokasi anggaran Rp.50.569.800.892,00, Realisasi Sisa Lebih Pembiayaan Anggaran(SILPA) sebesar Rp.22.836.223.879,74.

c. Realisasi Pendapatan Daerah pada Tahun Anggaran 2018 sebesar Rp.964.816.401.705,73 atau mencapai 96,37\% dari alokasi anggaran Rp.1.002.207.733.585,00, Realisai Belanja Daerah Tahun Anggaran 2018 sebesar Rp.982.955.077.365,89 atau mencapai 96.33\% dari alokasi anggaran Rp.1.020.380.935.465,00, Realisasi Surplus/Defisit 
pada Tahun 2018 sebesar (Rp.18.138.675.660,16) dari alokasi anggaran (Rp.19.273.201.880,00), Realisasi Pembiayaan Netto pada Tahun Anggaran 2018 sebesar Rp.23.273.203,50 atau mencapai 120,75\% dari alokasi anggaran Rp.19.273.201.880,00, Realisasi Sisa Lebih Pembiayaan Anggaran (SILPA) pada Tahun Anggaran 2018 sebesar Rp.5.134.528.090,34.

\section{Penyajian Pendapatan Laporan Keuangan Badan Pendapatan Daerah (BAPENDA) Kota Palopo.}

Dalam penyajian Laporan Keuangan, Badan Pendapatan Daerah (BAPENDA) Kota Palopo telah disusun dengan basis Kas pada Laporan Realisasi Anggaran dan Basis Akrual pada Laporan Operasional dan mengacu paca 4 karakteristik laporan keuangan yang merupakan ukuran-ukuran normatif yang perlu diungkapkan dalam penyajian informasi akuntansi sehingga dapat memenuhi tujuannya yaitu Relevan, Andal, Dapat Dibandingkan, dan Dapat Dipahami.

Analisis penerapan Peraturan Pemerintah Nomor 71 Tahun 2010 Tentang SAP dalam penyajian Laporan Keuangan pada BAPENDA Kota Palopo sebagai berikut:

a. Analisi Penyajian Pendapatan Laporan Realisasi Anggaran (LRA)

Laporan Realisasi Anggaran (LRA) menggambarkan perbandingan antara anggaran dan realisasinya dalam satu periode pelaporan dan menyajikan unsur-unsur Pendapatan, Belanja dan Surplus/Defisit.

b. Realisasi Pendapatan Daerah pada Tahun Anggaran 2017 sebesar Rp.28.953.473.231,00 atau mencapai 91,35\% dari alokasi anggaran sebesar Rp.31.696.180.400,00, Realisasi Belanja Pada Tahun Anggaran 2017sebesar Rp.11.736.568.796,00 atau mencapai 97,21\% dari alokasi anggaran sebesar Rp.12.072.837.500,00, Realisasi Surplus/Defisit pada Tahun Anggaran 2017 sebesar Rp.17.216.904.435,00 atau mencapai 87,74\% dari alokasi anggaran sebesar Rp.19.623.342.900,00.

c. Realisasi Pendapatan Daerah pada Tahun Anggaran 2018 sebesar Rp.31.913.669.568,00 atau mencapai 89,41\% dari alokasi anggaran sebesar Rp.35.694.450.000,00, Realisasi Belanja Pada Tahun Anggaran 2018 sebesar Rp.13.501.556.239,00 atau mencapai 91,55\% dari alokasi anggaran sebesar Rp.14.747.013.337,00, Realisasi Surplus/Defisit pada Tahun Anggaran 2018 sebesar Rp.18.412.113.329,00 atau mencapai 87,90\% dari alokasi anggaran sebesar Rp.20.947.436.663,00. 


\section{PENUTUP}

\section{Simpulan}

Berdasarkan hasil analisis yang telah dilakukan dalam meninjau Penerapan Standar Akuntansi Pemerintah pada Laporan Keuangan Badan Pengelolaan Keuangan dan Aset Daerah (BPKAD) dan Badan Pendapatan Daerah (BAPENDA) Kota Palopo Tahun 2017 dan 2018, dalam penelitian ini menemukan :

Perlakuan akuntansi pendapatan pada Pemerintah Daerah Kota Palopo telah sesuai dengan Peraturan Pemerintah Nomor 71 Tahun 2010 tentang Standar Akuntansi Pemeintah dimana dalam Laporan Realisasi Anggaran (LRA) diakui pada saat kas diterima di Kas Umum Daerah (KUD), dan dilaksanakan berdasarkan azas bruto, yaitu dengan membukukan penerimaan bruto dan tidak mencatat jumlah nettonya (setelah dikompensasikan dengan pengeluaran). Sedangkan dalam Laporan Operasional (LO) diakui sebagai penambah ekuitas dalam periode tahun anggaran yang bersangkutan dan tidak perlu dibayar kembali.

Penyajian akuntansi pendapatan pada Pemerintah Daerah Kota Palopo telah sesuai dengan Peraturan Pemerintah Nomor 71 Tahun 2010 tentang Standar Akuntansi Pemeintah dimana dalam Laporan Realisasi Anggaran (LRA) yaitu menggambarkan perbandingan antara anggaran dan realisasinya dalam satu periode pelaporan dan menyajikan unsure-unsur pendapatan, belanja, surplus/defisit, pembiayaan dan sisa lebih/kurang pembiayaan anggaran, sedangkan dalam Laporan Operasional (LO) menyajikan berbagai unsur pendapatan LO, beban, surplus/defisit dari kegaiatan operasional, surplus/defisit sebelum pos luar biasa, pos luar biasa dan surplus defisit LO yang diperlukan secara komperatif.

\section{Saran}

Penelitian ini hanya meninjau perlakuan dan penyajian Pendapatan pada Laporan Keuangan Badan Pengelolaan Keuangan dan Aset Daerah (BPKAD) dan Badan Pendapatan Daerah (BAPENDA) Kota Palopo Tahun 2017 dan 2018. Karena keterbatasan waktu sehingga belum dapat memberikan gambaran yang lebih jelasnya mengenai Laporan Keuangan Pemerintah dalam Standar Akuntansi Pemerintah Peraturan Pemerintah Nomor 71 Tahun 2010.

\section{DAFTAR PUSTAKA}

Agoes, Sukrisno dan Jan Hoesada. 2013. Bunga Rampai Auditing. Jakarta : Salemba empat 
Erlina, dkk. 2015. Akuntansi Keuangan Daerah Berbasis Akrual. Jakarta. Selemba Empat

Halim, Abdul. 2004. Akuntansi Keuangan Daerah. Penerbit Salemba Empat, Jakarta

Hariyanto, Agus. 2012. Penggunaan Basis Akrual Dalam Akuntansi Pemerintahan Di Indonesia. Dharma Ekonomi. No. 36 / Th. XIX / Oktober 2012.

Hartina, Silka. 2009. Analisis Penyajian Laporan Keuangan Daerah pada Pemerintah Kabupaten Langkat. Skripsi. Fakultas Ekonomi Universitas Sumatra Utara. Medan

Kawedar, Warsito, Abdul Rohman, dan Sri Handayani. 2008. Akuntansi Sektor Publik: Pendekatan Penganggaran Daerah dan Akuntansi Keuangan Daerah. Buku 2. Universitas Diponegoro. Semarang.

KSAP. Modul 2 - Kebijakan Akuntansi Pemerintah Daerah. Jakarta

Langelo, Friska; David Paul Elia Saerang dan Stanly Winylson Alexander. 2015. Analisis Penerapan Standar Akuntansi Pemerintahan Berbasis Akrual Dalam Penyajian Laporan Keuangan Pada Pemerintah Kota Bitung. Jurnal EMBA Vol.3 No.1 Maret 2015, Hal. 1-8

Niu, Fitri Ayu Lestari, H. Karamo., S. Tangkuman. 2014. Analisis Penerapan Pp. No. 71 Tahun 2010 Dalam Penyajian Laporan Keuangan Dinas Pendapatan Pengelolaan Keuangan Dan Aset DaerahKota Kotamobagu. Jurnal EMBA Vol.2 No.4 Desember 2014, Hal. 714-722.

Nurtanzila, Lastria, Jurnal Kebijakan \& Administrasi Publik. JKAP Vol 17 No 1 - Mei 2013 ISSN 0852- 9213

Peraturan Pemerintah Nomor 71 Tahun 2010 tentang Standar Akuntansi Pemerintahan.

Poerwadarminta, W.J.S. 2005. Kamus Umum Bahasa Indonesia. Edisi Ketiga. Jakarta: Balai Pustaka.

Rahman, Adi Nugroho, dan Zulaikha. 2012. "Faktor-Faktor Yang Mempengaruhi Kemauan Untuk Membayar Pajak Dengan Kesadaran Membayar Pajak sebagai Variabel Intervening (Studi Kasus Pajak Orang Pribadi Yang Melakukan Pekerjaan bebas yang Terdaftar di KPP Pratama Semarang Satu)". Diponegoro Journal Of Accounting. Vol.1 No 2. 
Ratag, Suryani Miyoko. 2013. Jurnal, Perlakuan Akuntansi Capital Expenditure Dan Revenue Expenditure Pada Pt. Bank Sulut. Fakultas Ekonomi Jurusan AkuntansiUniversitas Sam Ratulangi Manado. Manado. Jurnal EMBA Vol.1 No.3 Juni 2013, Hal. 179-189.

Rintiani, Wasik Nista, Jurnal, Evaluasi Penyajian Laporan Keuangan Pemerintah Daerah Kota Surabaya Berdasarkan PP No. 71 Tahun 2010, Universitas Negeri Surabaya

Rohman, Arif. 2009. Memahami Pendidikan dan Ilmu Pendidikan. Yogyakarta: Laks Bang Mediatama.

Sandy, Rachmat Ramadhan, dkk., 2013, Jurnal, Analisis Penyajian Laporan Keuangan Pemerintahaan Kabupaten Tulungagung, Universitas Brawijaya: Malang

Sampel, Indra Franselski, L. Kalangi., T. Runtu. 2015. Analisis Kesiapan Pemerintah Kota Manado Dalam Penerapan Peraturan Pemerintah Nomor 71 Tahun 2010 Mengenai Standar Akuntansi Basis Akrual. Jurnal EMBA. Vol.3 No.1 Maret 2015, Hal.621-630

Siregar, Baldric, 2017. Akuntansi Sektor Publik. Yogyakarta. UPP STIM YKPN

Syahrul dan Muhammad Afdi Nizar, 2000, "Kamus Istilah-istilah Akuntansi", Cetakan Pertama, Citra Harta Prima, Jakarta.

Tanjung, Abdul Hafiz. 2012. Akuntansi Pemerintahan Daerah. Bandung: Alfabeta. 